\title{
Political shocks and asset prices
}

\author{
Daniel Carnahan ${ }^{1}$ and Sebastian Saiegh ${ }^{2 *}$ \\ ${ }^{1}$ University of California Los Angeles, Los Angeles, CA, USA and ${ }^{2}$ University of California San Diego, La Jolla, CA, USA \\ ${ }^{\star}$ Corresponding author. Email: ssaiegh@ucsd.edu
}

(Received 26 August 2020; revised 22 June 2021; accepted 27 June 2021)

\begin{abstract}
We estimate how asset prices respond to a range of political shocks, including changes in a country's economic stewardship, national elections, coup d'états, wars, and terrorist attacks. Using an event study approach and daily prices from the Buenos Aires exchange (Argentina) between 1967 and 2020, we find that stock-market volatility increases in the days immediately following major policy-shifting events. These results hold irrespective of whether returns are measured in nominal terms, in local consumption units, or in US dollars. The most significant increase in post-event risk is associated with irregular government turnovers. Volatility also increases in the days immediately following a defeat in an international war, national elections, and changes in the country's economic stewardship. No changes in stock-market volatility occur, however, after terrorist attacks or when the date of a new administration's inauguration is publicly known and determined sufficiently far in advance.
\end{abstract}

Key words: Argentina; comparative political risk; Latin American politics; political economy

\section{Introduction}

Investors concerned about non-commercial risks need to consider their exposure to political events that may affect the value of their assets. These political risks can originate in specific government actions, such as laws or regulations. They can also arise when countries experience bouts of political instability, such as wars or abrupt changes in government. For example, Girardi and Bowles (2018) document that a substantial increase in share values took place in the Santiago stock exchange in the trading day immediately following the 1973 military coup against Salvador Allende. The movement of asset prices in Indonesia between 1995 and 1997 is another case in point. The Jakarta Composite Index consistently declined during that period whenever the market was hit by rumors about Suharto's health (Fisman, 2001).

Recent research has examined how market valuations respond to the policy uncertainty associated with these kinds of events, including wars, acts of terror, revolutions, coups, and national elections. Most of the literature, however, focuses on specific types of events in a single-country setting, or on a range of political shocks in a multiple-country setting. The former strategy cannot account for the differential impact of various types of political shocks on financial markets; whereas multi-event, cross-national studies face significant identification problems posed by confounders, reverse causality, and measurement error bias.

In this study, we leverage Argentina's checkered political history to conduct a multi-event analysis in the context of a single country. We combine daily prices from the Buenos Aires exchange between 1967 and 2020 with detailed information on major political shocks in the country, including changes in its economic stewardship, national elections, coup d'états, wars, and terrorist acts. Financial markets incorporate new information into asset prices very quickly. Therefore, we employ an event study approach and exploit the precise timing of these events to capture their

(C) The Author(s), 2021. Published by Cambridge University Press on behalf of the European Political Science Association. This is an Open Access article, distributed under the terms of the Creative Commons Attribution licence (https://creativecommons.org/licenses/by/4.0/), which permits unrestricted re-use, distribution, and reproduction in any medium, provided the original work is properly cited. 
effect on variance risk. Specifically, we adopt a sufficiently narrow event window to minimize the presence of contaminating information. Then, we use the variance forecast from a $\operatorname{GARCH}(1,1)$ model to compare changes in volatility before and after an event's public disclosure.

Under the null hypothesis, the variance risk following a political event should be indistinguishable from the one before the news of the event breaks. Regarding all the events included in this study, irrespective of their type, our results indicate that volatility increases in the firsttrading day when the Argentine stock market can respond to the news of these events, compared to its chronological neighbor, the trading day before the events become publicly known.

An examination of how the different types of policy-shifting events affect asset prices reveals that the most significant increase in post-event risk is associated with irregular government turnovers (coup d'états, presidential death, and resignations). The change in volatility associated with this type of event amounts to approximately 100 percent on average, when returns are expressed in US dollars. Volatility also increases from a minimum of 15 percent to a maximum of 62 percent in the days immediately following a defeat in an international war, national elections, and changes in the country's economic stewardship. No changes in stock-market volatility occur, however, after terrorist attacks or when the date of a new administration's inauguration is publicly known and determined sufficiently far in advance. These results hold irrespective of whether market returns are measured in nominal terms, in local consumption units, or in US consumption units. They are also robust when we exclude events that took place during a three-day window with non-consecutive calendar days to account for weekend/holiday effects, as well as when we replicate the analysis using intraday price movements. As such, our findings highlight the sensitivity of asset prices to unexpected, policy-shifting, events.

The remainder of the paper is organized as follows. We discuss the relationship between policy uncertainty, volatility, and material prosperity in Section 2. In Section 3, we describe our data, introduce our key variable of interest, present our identification strategy, and discuss our estimation details. In Section 4, we report our main empirical findings. We examine these results in Section 5. A final section concludes.

\section{Policy uncertainty, volatility, and growth}

A well-established literature in political economy examines how policy uncertainty affects economic activity. Expected returns on investment are less predictable when government regulations are hyperactive, erratic (or both). Under these circumstances, households and firms may adopt a cautious stance (Bernanke, 1983; Dixit and Pindyck, 1994). Research using the news-based Baker et al. (2016) index finds a relationship between policy uncertainty and return volatilities in the United States (Pastor and Veronsi, 2013; Brogaard and Detzel, 2015). Other studies also find a positive relationship between political uncertainty and financial volatility in different contexts (Bittlingmayer, 1998; Boutchkova et al., 2012; Liu et al., 2017). ${ }^{1}$

Weaker investments in long-term projects may, in turn, undermine growth. The empirical evidence seems to corroborate this argument, as policy uncertainty is negatively correlated with both investment and output growth (Aizenman and Marion, 1993; Ramey and Ramey, 1995; Baker et al., 2020). When household and firms withhold irreversible investments, they put their money into relatively liquid securities, so that they will be able to move quickly once their uncertainty about government policy is resolved. Therefore, the fraction of market transactions that are relatively short-term and speculative increases during periods of government uncertainty. In addition, equity markets reveal investors' assessments of how regulatory, fiscal, and monetary policy impact economic activity into the indefinite future. These expectations are conveniently summarized in present value terms. Finally, as Kelly et al. (2016) note, by raising the firms' cost of capital, policy uncertainty can ultimately depress investment and real activity.

\footnotetext{
${ }^{1}$ See Dai and Zhang (2019) for a recent survey of this literature
} 


\subsection{Political shocks}

Pastor and Veronesi (2013) develop a general equilibrium model in which stock prices respond to political signals. They assume that governments care about the welfare of the average investor as well as other objectives. The latter are conceived as political costs, or benefits, associated with any policy change. For example, the government may need to burn political capital to implement a certain policy. Alternatively, a new policy may allow the government to curry favor with a given constituency.

To capture the difficulty that investors face in predicting policy outcomes, the authors assume that political costs/benefits are randomly determined. Therefore, although government actions are not fully predictable, investors can rely on a host of political signals (such as appointments, dismissals, official pronouncements, etc.) to update their beliefs about future policy decisions. Given this learning process, political shocks can be conceived as the differences between the political signals and their expectations. As such, these shocks shape investors' beliefs about which government policy is likely to be adopted in the future. The results Pastor and Veronesi (2013) indicate that the effect of political shocks on investors' expected returns is bigger when the sensitivity of marginal utility to political costs/benefits is larger, when the uncertainty about the political costs/benefits is larger, as well as when the accuracy of the political signals is larger.

Investors typically rely on publicly available information to forecast what the government will do in the future. Although the universe of "political signals" is enormous, most studies have focused on how markets react to military and political crises (Amihud, and Wohl, 2004; Rigobon and Sack, 2005; Zussman et al., 2008; Berkman et al., 2011), terrorist attacks (Zussman and Zussman, 2006; Arin et al., 2008; Berrebi and Klor, 2008; Brounrn and Derwall, 2010; Chesney et al., 2011), as well as revolutions, coup d'états and leaders' deaths while in office (Jones and Olken, 2005; Dube et al., 2011; Dasgupta and Ziblatt, 2015; Girardi and Bowles, 2018; Incerti and Incerti, 2019; Baker et al., 2020).

In addition, a related stream of literature on political events and financial volatility focuses on "normal" politics in democracies (Bernhard and Leblang, 2006; Leblang and Satyanath, 2008). For example, the effect of national elections on asset prices has received a considerable amount of attention. These studies show that the winning candidate's partisanship (left versus right), as well as the predictability of the electoral outcome can affect stock-market returns (Pantzalis et al., 2000; Leblang and Mukherjee, 2004; Bialkowski et al., 2008; Boutchkova et al., 2012; Sattler, 2013; Kelly et al., 2016; Carnahan and Saiegh, 2020).

Following the existing literature, as well as the analysis in Pastor and Veronesi (2013), we consider a collection of events that exhibit sufficient variation to identify the effect of political uncertainty and signal precision on market volatility. Specifically, we focus on the following policy-shifting events: changes in a country's economic stewardship; changes in a country's administration; national elections; wars; and terrorist attacks. Some of these events provide more precise political signals than others (e.g., coups versus successions that take place according to constitutional rules); some events are more unpredictable than others (e.g., contested versus uncontested elections); and, some events should affect all firms (i.e., they cannot be diversified away), whereas others are usually a source of idiosyncratic rather than systematic risk (e.g., changes in economic stewardship versus terrorist attacks).

\section{Empirical design}

Studies of the relationship between politics and stock market returns have either focused on a specific type of event in a single-country setting, or on a range of political shocks in a multiplecountry setting. Examining a single category of events, however, may hinder one's ability to fully understand the differential impact of various types of political shocks on financial markets. On the contrary, conducting a multi-event study in multiple countries requires significant caution. As

\footnotetext{
${ }^{2}$ See Wisniewski (2016) for a good survey of this literature.
} 
Park (2004) notes, identifying institutional differences in national stock markets, estimating cross-country abnormal returns, accounting for macroeconomic conditions in different countries, and controlling for confounding events can be extremely challenging. ${ }^{3}$

We take advantage of Argentina's unstable political history to conduct a multi-event analysis in the context of a single country. This strategy allows us to avoid the pitfalls of multi-country event studies while giving us enough latitude to establish comparisons across different types of political shocks. Critical to our approach is the fact that the country experienced numerous and different types of major policy-shifting events during the period under study, including sudden political crises, terrorist attacks, and even an international war. ${ }^{4}$

\subsection{Data and measurement}

We combine daily prices from the Buenos Aires Stock Exchange (Bolsa de Comercio de Buenos Aires) with detailed information on major political shocks in Argentina. Due to data availability on stock-market prices, we focus on the period between 1967 and 2020 . We examine eight types of policy-shifting events: changes in the country's economic stewardship (with and without a change in administration); changes in the country's administration (including coup d'états, resignations, and deaths while in office, as well as planned successions); national elections; wars; and terrorist attacks. Our starting point is Keesing's Record of World Events. This source provides a detailed, accurate, and neutral account of all major political events around the world. ${ }^{5}$

Our data include the date and type of event. Assigning each event to the appropriate trading day is crucial for our analysis. We rely on media coverage to identify each event's exact announcement date. Our sources are the two major Argentinian newspapers, La Nación, and Clarín, as well as two English-language publications, The New York Times, and the British daily The Times. Table 1 reports the number of events in our sample by event type, as well as the dates of their first and last occurrence. There are 125 distinctive events in our sample. ${ }^{6}$

Note that the numbers in Table 1 do not "add up" because some types of events are not mutually exclusive: for example, we count 62 instances where a person in charge of managing Argentina's economy changed, including 47 cases where these officials changed without a modification in the country's administration. But, we only count 21 cases where a change in the composition of the government took place. The reason is that there are eight cases where the leaders of a new government decided to keep the previous administration's economic stewardship.

We consider that a change in the country's economic stewardship occurs whenever the economic minister (Ministro de Economía) and/or the Central Bank governor leaves office. Although other high-ranking officials also manage important elements of the country's macroeconomic policies, these policy-makers are subordinate to our selected economic stewards, and tend to follow their bosses in leaving office. Therefore, we decided to exclude these underlings from our analysis. We also excluded from the analysis public officials (usually another cabinet member) who may serve as acting, interim, economic ministers for a just a few days until a new one is appointed. Even when we restrict our focus to the country's top economic policy-makers, there is an abundance of cases in our sample. A total of 39 different people occupied the office of economic minister; and 34 different persons served as Central Bank governors in the 53 years between 1967 and 2019.7

\footnotetext{
${ }^{3}$ Except for Kelly et al. (2016), most multi-event, cross-national studies, fall short of their intended goals due to these problems.

${ }^{4}$ Argentina's unusual political experience has not gone unnoticed. For example, as Przeworski (2005) notes, no democracy ever fell in a country with a per capita income higher than that of Argentina in 1975, \$6055 in 1985 purchasing power parity dollars (PWT release 5.6). See online Appendix A for more details about the Argentine case.

${ }^{5}$ http://keesings.com.

${ }^{6}$ We provide the full list of events in online Appendix G.

${ }^{7}$ Three economic ministers served under different administrations: Jose Maria Dagnino Pastore, Jorge Wehbe, and Domingo Cavallo. Excluding interim officers, the average tenure of an Argentine economic minister during this period
} 
Table 1. List of events

\begin{tabular}{llll}
\hline Event & Total number & First occurrence & Last occurrence \\
\hline $\begin{array}{l}\text { Change in the country's economic stewardship } \\
\text { Change in the Country's Economic stewardship }\end{array}$ & 62 & Tuesday, 10 June 1969 & Tuesday, 10 December 2019 \\
$\quad$ (without a change in government) & & Tuesday, 10 June 1969 & Tuesday, 20 August 2019 \\
$\begin{array}{l}\text { Change in administration } \\
\text { Irregular change in administration }\end{array}$ & 21 & Thursday, 18 June 1970 & Tuesday, 10 December 2019 \\
Planned succession & 9 & Thursday, 18 June 1970 & Thursday, 3 January 2002 \\
National election & 12 & Friday, 25 May 1973 & Tuesday, 10 December 2019 \\
Terrorist act & 28 & Sunday, 11 March 1973 & Sunday, 27 October 2019 \\
International war & 27 & Friday, 29 May 1970 & Monday, 18 July 1994 \\
\hline
\end{tabular}

${ }^{a}$ There is only one incident involving an international war. We list the beginning of the war as the first occurrence, and its end as the last occurrence.

Regarding changes in the country's administration, we consider that an event of this type occurs whenever a new administration is inaugurated, even if the incumbent president was reelected. ${ }^{8}$ Not all successions, although, take place in accordance with constitutional rules. In addition to presidential turnover due to elections, other irregular, as well as unexpected, changes in the country's top leadership also occur in our sample. These include coup d'états, a presidential death, as well as a few resignations. Of the 21 changes in the country's administration, nine of them happened in an irregular way during the period under study: one coup d'état against a constitutionally elected civilian administration; three coups within military, unconstitutional, administrations; four resignations; and, one president died in office (Juan Domingo Peron, in 1974). As with economic ministers, we excluded from the analysis public officials who served as acting, interim, presidents for a just a few days until a new one was appointed. In total, 20 different persons occupied the presidency; for an average tenure of roughly 32 months. ${ }^{9}$

In the case of national elections, we include both presidential as well as legislative (midterm elections). We also consider the country's peculiar brand of primaries as a significant electoral event. Introduced in 2009, the simultaneous and mandatory open primaries (Primarias Abiertas Simultáneas y Obligatorias, PASO) serve in practice as a nationally representative poll revealing the share of votes that candidates are expected to receive in the actual presidential elections. ${ }^{10}$ A total of 28 national elections were held in the period between 1967 and 2020. Most of these electoral contests (26) took place, however, after 1982.

Unlike national elections, coding terrorist acts is not a straightforward task. Following Berrebi and Klor (2010), we define a terrorist attack as a premeditated, politically motivated act of violence perpetrated against noncombatant targets by domestic or international clandestine groups,

was 15 months. The longest tenure corresponds to Domingo Cavallo, who was appointed on 29th January 1991, and resigned on 26th July 1996. Miguel Roig's tenure is the shortest one. He was appointed on 9th July 1989, and died of a heart attack, while in office, six days later. Three Central Bank governors served multiple times: Egidio Ianella (3), Enrique García Vázquez (2), and Javier A. González Fraga. Excluding interim officers, the average tenure of a Central Bank governor during this period was 17 months. The longest tenure corresponds to Roque Fernandez, who was appointed on 5th February 1991, and resigned on 26th July 1996. Egidio Ianella holds the shortest tenure (24th November to 20th December 1989).

${ }^{8}$ Immediate reelection for Argentine presidents was banned after 1955, until the constitutional reform of 1994 introduced that possibility again.

${ }^{9}$ Most of the cases of planned successions (11 out of 12) correspond to the inauguration date of democratically elected presidents. The sole exception is the transfer of power between two members of the so-called National Reorganization Process (Proceso de Reorganización Nacional) military regime of 1976-1983. Its members stipulated that rulers should be bound by a five-year term. The rule, however, was only observed when General Roberto Viola succeeded General Jorge Rafael Videla in 1981.

${ }^{10}$ Most elections in our sample were held simultaneously throughout the country. In a few years, legislative elections took place at different dates, varying by district. In those cases, we took the date or the earliest contest held in one of the country's largest, and thus, most representative, districts (i.e., the province of Buenos Aires, Buenos Aires City, Cordoba, Santa Fe, and Mendoza). 
usually intended to influence an audience. In addition, we adopt the following criteria to identify the most salient, publicly known, fatal attacks against non-combatants that occurred on Argentine soil between 1967 and 2020. First, we consider unclassified information based on Argentine media coverage. Second, we only include in our sample terrorist attacks that received front-page coverage by Clarín, one of the country's most prominent newspapers. ${ }^{11}$

Based on these criteria, a total of 29 terrorist acts exist in our sample. Most of them (26) occurred in the 1970s, when the country faced a surge in political violence. The remaining three include the 1989 attack on La Tablada barracks, as well as the 1992 suicide bombing of the Israeli embassy in Buenos Aires, and the 1994 suicide bombing of the Argentine Israelite Mutual Association (Asociación Mutual Israelita Argentina, AMIA) building in Buenos Aires. These terrorist acts varied in the identity of the perpetrators as well as in the number of confirmed fatal casualties (ranging from 1 to 86). Yet, they all had significant shock value, especially those involving prominent political figures, such as the assassinations of former Argentine president Pedro Eugenio Aramburu; former interior minister Arturo Mor Roig; the leader of Argentina's national trade union federation, José Ignacio Rucci; and national legislator Rodolfo Ortega Peña.

Finally, another major and extremely unusual policy-shifting event, the war between Argentina and the United Kingdom over the Falklands/Malvinas Islands, also took place during the period under study. The conflict began on 2 April 1982, when Argentina occupied the islands by surprise, and ended on 14 June 1982, when the commander of the Argentine forces (General Mario Benjamin Menéndez) surrendered to British Major General Jeremy Moore. Unlike the other types of events discussed above, this was a single instance. As such, we give this event a special statistical treatment in the analyses presented below.

To examine how the Argentine stock market reacted to these different types of events, we examine the General Index of the Buenos Aires Stock Exchange (Bolsa de Comercio de Buenos Aires). The index, which represents the prices of the market's most important stocks, is based on the quotes of ordinary shares, and adjusted to reflect the quotes' bids and withdrawals, as well as changes in firms' social capital. It includes 15 sector indices for food, banks, insurance, beverages, trade and imports, construction, finance, raw materials, chemicals, manufacturing, metals, paper and printing, utilities, textiles, and miscellaneous. We construct daily returns using data for the period between 2nd January 1967 and 30th March $2020 .^{12}$

As it is standard in finance, we need to control for global conditions. As our benchmark index, we use the S\&P 500, one of the best representations of the US stock market. A capitalizationweighted index, the S\&P 500 measures the performance of 500 large companies listed on stock exchanges in the United States. ${ }^{13}$ Note that the Buenos Aires Stock Exchange index is measured in local consumption units whereas the return on the S\&P index is measured in US consumption units. Between 1967 and 2020, large real exchange rate depreciations took place in Argentina. In addition, the Argentine economy has a long history of high inflation. During the period under

\footnotetext{
${ }^{11}$ The newspaper's front-page for every day in our sample period can be consulted at: https://tapas.clarin.com/.

${ }^{12}$ We obtained the data from www.globalfinacialdata.com. They were sourced from the Anuario Bursatil, Buenos Aires: Bolsa de Comercio de Buenos Aires. The original index can be found in the file ARIVBNGD with the base of 29 December $1966=1$. Because of Argentina's inflation, two adjustments were made in the series to make the data more legible. From 1967 through 1982, the base is 29 December $1977=100$, from 1983 through 1987, the base is 29 December $1977=0.1$, and from 1988 on, the base is 29 December $1977=0.00001$. The General Index was revised in 2001 with data recalculated back to 30 June 2000 with 30 June $2000=19,570.98$. The General Stock Exchange Index (30 December 1977=0.00001) is based on the quotes of ordinary shares and is used to obtain a wider historical coverage.

${ }^{13}$ We obtained the data from www.globalfinacialdata.com. They were sourced from Standard and Poor's Security Price Index Record, New York: Standard and Poor's; Standard and Poor's, Outlook, New York: Standard and Poor's; and Standard and Poor's, Statistical Service, New York: S\&P. The original S\&P 500 introduced in 1957, included 425 industrials, 25 rails, and 50 utilities. The index was revised on 1 July 1976 when the rail index was dropped, and was replaced by the Transportation Index, and a Financial Index was added. On 6 April 1988, exact numerical allocations were abandoned allowing the sectoral composition of the S\&P 500 to change as new stocks were removed and added to the index.
} 
study, the average annual inflation rate was roughly 190 percent (with a historical maximum of 3079 percent in 1989).

To address these issues, we measure the daily returns of the Buenos Aires Stock Exchange's General Index in local consumption units both in nominal as well as in real terms. We also calculate real returns expressed in US consumption units. Our results are quite similar irrespective of how market returns are measured.

Following the standard practice in the literature, we use logarithmic returns to calculate both indices' daily cumulative returns:

$$
r_{t}=\ln \left(\frac{I_{t}}{I_{t-1}}\right)
$$

where $\ln$ is the natural logarithm operator, and $I$ represents the total return from holding the market index between the periods $t$ and $t-1$ (which correspond, in this case, to two consecutive trading days).

Determining how government policies affect aggregate corporate value is a non-trivial task. Some actions affect the value of firms directly, and others indirectly through general equilibrium channels. In addition, most government interventions tend to have distributive consequences across different sectors of the economy. For example, a policy change that increases the relative prices of tradables in terms of non-tradables should raise the value of firms in the former sector and reduce it in the latter. Therefore, as Cruces and Garcia-Cicco (2012) note, the actual effect of the policy change on the aggregate stock-market index would depend on its composition.

Our main interest is, thus, not on returns per se, but rather on the second moment of the return distribution. Larger swings in price are riskier than smaller swings in price; and more frequent price changes are riskier than less frequent price changes. It is, thus, common for investors to use variance (or, its square root, the standard deviation) as a measure of how far a security's return deviates from its average during a given period. We model the joint process governing stock-market returns and the variance of those returns using a generalized autoregressive conditional heteroskedasticity (GARCH) framework. This statistical approach seeks to replicate how traders predict the conditional volatility of returns, as it incorporates in each period the most recent forecast error as well the previous period's forecasted variance.

We adopt the following model of the return-generating process:

$$
\begin{gathered}
r_{t}^{\mathrm{BA}}=\alpha+\beta r_{t}^{\mathrm{SP}}+\varepsilon_{t} \\
\varepsilon_{t} \sim N\left(0, h_{t}^{2}\right) \\
h_{t}^{2}=\gamma_{0}+\gamma_{1} \varepsilon_{t-1}^{2}+\gamma_{2} h_{t-1}^{2}
\end{gathered}
$$

where $r_{t}^{\mathrm{BA}}$ and $r_{t}^{\mathrm{SP}}$ are vectors of returns for the Buenos Aires index and S\&P 500, respectively; $h_{t}^{2}$ is the conditional variance of $\varepsilon_{t}$; and $\gamma_{0}, \gamma_{1}$, and $\gamma_{2}$ are the coefficients of a $\operatorname{GARCH}(1,1)$ specification. ${ }^{14}$

\footnotetext{
${ }^{14} \mathrm{We}$ also examined the asymmetric effect of shocks on volatility using the following absolute threshold-GARCH (ATARCH) process:

$h_{t}^{2}=\gamma_{0}+\gamma_{1} \varepsilon_{t-1}^{2}+\gamma_{2}\left|\varepsilon_{t-1}\right|\left(\varepsilon_{t-1}>0\right)+\gamma_{3} h_{t-1}^{2}$

where $\left(\varepsilon_{t-1}>0\right)$ is an indicator function returning one if $\varepsilon_{t-1}>0$, and zero otherwise. This term allows the effect of unanticipated innovations to be asymmetric about zero. The results indicate that the coefficient $\gamma_{2}$ is statistically
} 
Following the approach in Dubofsky (1991) and Clayton et al. (2005), we use the variance forecast from the $\operatorname{GARCH}(1,1)$ model to calculate our key variable of interest, the volatility ratio (VR). We compute it as the natural logarithm of the ratio of the estimated variance at time $t$ to the estimated variance at time $t-1$. This measure is equivalent to the percentage increase of the conditional variance relative to the previous day, allowing us to consider how volatility changes, not its level. By looking at changes, not levels, we can control for differences in the conditional variance in different time periods. ${ }^{15}$

\subsection{Identification strategy}

Financial markets quickly incorporate new information that is publicly available into asset prices (Fama, 1970). That happens because markets are forward-looking; meaning that an asset's price does not represent the value of its past performance. Instead, the assets' current price represents the value investors assign to its future performance. When potential news indicates that a security may be worth more in the future, investors will buy it up to the point where the asset is no longer undervalued. The result is that asset prices immediately reflect current expectations of future value. Therefore, only a truly unexpected event would trigger portfolio rebalancing and lead to an increase in short-term volatility, as investors update their beliefs and search for new asset prices.

In addition, to credibly claim that the market responded to a specific event, it is imperative to show that such reaction is not driven by other confounders. For example, the release of another piece of unexpected news, such as a change in global real interest rates, a devaluation of the domestic currency, or some other market-related information disclosure. The potential presence of contaminating news is particularly problematic when the exact date of the event of interest is uncertain and/or when the window around the event is too broad (Dyckman et al., 1984). But, when the precise timing of the event under consideration is known, the adoption of a very narrow window around its announcement should allow one to minimize the presence of contaminating information.

To make sure that our analysis is free from contaminating information, we adopt the period of three trading days centered on each political shock as our event window. The days are identified as $-1,0,1$, with day zero denoting the trading day immediately before the news of a domestic policy-shifting event breaks. Day one is defined as the first day the Argentine stock market could respond to the news of the event. ${ }^{16}$ Day minus one is the trading day preceding the day before the event became publicly known. An examination of all the stories that received frontpage coverage by the Argentine newspaper Clarin in each of these three-day windows reveals that no other major political, macroeconomic, or stock-market-related news were concurrently released. We are, thus, confident that our event window around each event is sufficiently narrow and free from contaminating information to produce unbiased estimates of the impact of political shocks on financial volatility.

Once we establish its appropriate three-day window, we can calculate the pre-event volatility ratio for each political shock $v$ in our sample as:

$$
V R_{v}^{\kappa}=\ln \left(\frac{h_{t=0}^{2}}{h_{t=-1}^{2}}\right)
$$

\footnotetext{
indistinguishable from zero when returns are measured in nominal local consumption units or in real US consumption units. This means that negative shocks have a similar effect on the index volatility than positive ones. In the case of returns measured in real local consumption units, the coefficient $\gamma_{2}$ is positive, and statistically significant indicating that that positive innovations (unanticipated price increases) are more destabilizing than negative innovations. Therefore, we use the absolute threshold-GARCH (ATARCH) specification to estimate the return-generating process when the index returns are measured in real local consumption units.

${ }^{15}$ Using the log transformation also reduces the skewness of the underlying data.

${ }^{16}$ In cases where the event's public disclosure came after the close of trading, we adjust day one accordingly.
} 
and its post-event volatility ratio as:

$$
V R_{v}^{\tau}=\ln \left(\frac{h_{t=1}^{2}}{h_{t=0}^{2}}\right) .
$$

The pre-event volatility, $V R_{v}^{\kappa}$, indicates the extent of contaminating information in the threeday window, and/or investors' anticipation of possible news. The post-event volatility, $V R_{v}^{\tau}$, on the other hand, allows us to gauge the market's ability to quickly and fully absorb the information flowing to it. The following three hypotheses illustrate what our measure means, and how to interpret it:

$H_{0}$ : If $V R_{v}^{\kappa}=0$ and $V R_{v}^{\tau}=0$, then both pre- and post-event volatility remain unchanged from previous levels.

$H_{0}^{\prime}$ : A positive value of $V R_{v}^{\kappa}$, combined with $V R_{v}^{\tau} \leq 0$ indicates that an increase in pre-event volatility exists, while post-event volatility is either decreasing or does not change.

$H_{A}$ : A positive value of $V R_{v}^{\tau}$, combined with $V R_{v}^{\kappa} \leq 0$ indicates that an increase in post-event volatility exists, whereas pre-event volatility is either decreasing or does not change.

Under the null hypothesis $H_{0}$, asset prices are not affected by the event $v$. According to $H_{0}^{\prime}$, the market reaction: (a) is driven by extraneous news released on the eve of the event $v$; or (b) indicates that the event $v$ did not take investors by surprise. Therefore, only after observing the combination of $V R_{v}^{\tau}$, and $V R_{v}^{\kappa}$ postulated in $H_{A}$, we can conclusively assert that asset prices responded to the event $v$. We empirically test these hypotheses in the following section. But, before reporting on the results of our analyses, we need to discuss our estimation details, as well as our inferential approach.

\subsection{Estimation and inference}

To examine the effect of political shocks on financial volatility we use an event study approach. Its component steps are well known. Based on an estimation window prior to the analyzed event, the method estimates what the normal stock returns should be at the day of the event and several days prior and after the event (i.e., during the event window).

In studies using daily data, an estimation window going from day -250 to day -30 relative to the event date is often (somewhat arbitrarily) chosen. As Aktas et al. (2007) note, this conventional choice is not free of complications. If unrelated events are present during the chosen estimation window, the estimation of the return-generating process parameters may be biased. ${ }^{17}$ To address this issue, we adopt the whole period between 1 January 1967 and 30 March 2020 as our estimation window. In conjunction with our focus on changes in volatility rather than levels, and the identification strategy delineated above, using the whole sample to estimate the long-run average daily variance of the Buenos Aires Stock Exchange's General Index reduces the potential effect of contaminating events.

Our sample contains multiple volatility ratios-event type combinations, and it is desirable to aggregate results into a single hypothesis test. Specifically, our goal is to compare how different kinds of policy-shifting shocks affect asset prices, rather than the effect of a single, idiosyncratic, event on stock-market volatility. We group all the events into different categories $c \in E$ as

\footnotetext{
${ }^{17}$ Savickas (2003) proposes the use of a GARCH $(1,1)$ model with an event dummy variable to control for the influence of contaminating events. This solution, however, comes at the cost of an increase in persistence (Aktas et al., 2007).
} 
outlined in Table 1, except for war, which is a singleton. Then, we calculate an equally weighted average of pre- and post-event volatility for each one of them: $\overline{V R_{v=c}^{\kappa}}$, and $\overline{V R_{v=c}^{\tau}}$.

It is reasonable to expect that aggregating individual events into categories could create crosssectional variation in each group's volatility ratios (Harrington and Shrider, 2007). Therefore, we do not use these averages to test our main hypotheses. Instead, we use a test statistic. In the case of the post-event volatility, it takes the form of:

$$
t_{c}^{\tau}=\frac{\overline{V R_{v=c}^{\tau}}-V R_{0}}{\text { s.e. }\left(\overline{V R_{\nu=c}^{\tau}}\right)},
$$

where $V R_{0}$ is the expected volatility ratio under the null. Therefore, for example, in the case of post-event volatility, we want to reject $\overline{V R_{v=c}^{\tau}}=0$; therefore, we should set $V R_{0}=0$. The test statistic for the pre-event volatility, $t_{c}^{\kappa}$, can be calculated in a similar way.

The next step is to compute the observed significance levels for these test statistics. If the returns were normally distributed, theoretical values could be used. The non-normality of daily returns, however, is well documented in the literature. As it turns out, the residuals of our return-generating model-from which the values of our key measure of interest are calculated-are not very close to a normal distribution. In addition, the coefficients of our GARCH specification indicate that the variance process mean reverts slowly. Therefore, in our calculations of the volatility ratios, the denominator is larger than the numerator more frequently than the other way around. As a result, despite our use of the log transformation, the distribution of the volatility ratios exhibits considerable skewness.

To address this issue, and make certain that we do not make incorrect inferences, we evaluate the statistical significance of our test statistics following the approach in Białkowski et al. (2008). Specifically, we rely on bootstrapped p-values generated using the following iterative procedure:

(1) Let $n_{c}$ be the measure of a set composed by type- $c$ events, where $n_{c}$ is positive and integervalued; and $\sum_{c=1}^{E} n_{c}=N$, where $N$ is the total number of distinctive events in our sample. To simulate the conditions under which the null hypothesis is true, we restrict our attention to observations corresponding to days in which the events listed in Table 1 did not take place. Then, we randomly draw with replacement from this sample $n_{c}$ observations, to match the number of events in each category $c \in E$.

(2) For each category $c \in E$, we compute the average volatility ratio $\overline{V R_{c}}$ and its associated test statistic, $t_{c}^{\eta}$ with $V R_{0}=0$, for the randomly drawn sample of $n_{c}$, using these observations' volatility ratios calculated from our $\operatorname{GARCH}(1,1)$ specification's estimated conditional variances.

(3) We repeat steps (1) and (2) 10,000 times and sort the collection of test statistics $t_{c}^{\eta}$ in the ascending order to obtain the empirical distribution.

The next step is to evaluate the statistical significance of our test statistics. Suppose that one wants to reject $\overline{V R_{v=c}^{K}}>0$. In this case, the p-value can be defined as the number of bootstrapped test statistics $t_{c}^{\eta}$ whose values exceed the value of the pre-event test statistic, $t_{c}^{\kappa}$, divided by the number of replications (in this case, 10,000). Using a two-tailed test, one should reject $\overline{V R_{v=c}^{\kappa}}>0$ at the 95 percent confidence level if there are 250 or more test statistics $t_{c}^{\eta}$ with values that are higher than the value of $t_{c}^{\kappa}$. Following this logic, we calculate $\operatorname{Pr}\left(t_{c}^{\eta}>t_{c}^{\kappa}\right)$ and $\operatorname{Pr}\left(t_{c}^{\eta}>t_{c}^{\tau}\right)$ to evaluate the combination of pre- and post-event volatilities postulated in $H_{A}$. 
Nominal Returns

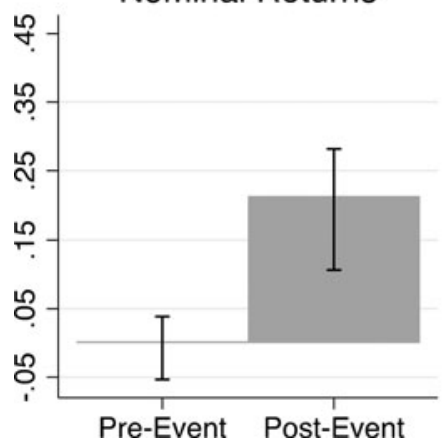

Real Returns

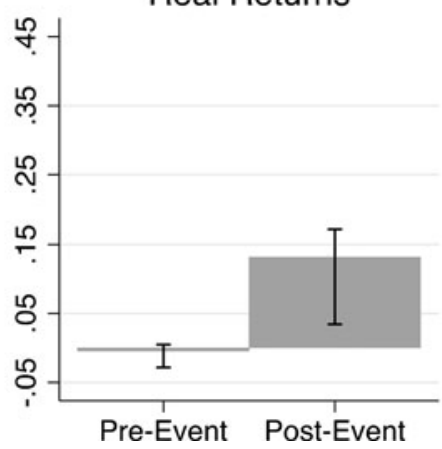

Returns in USD

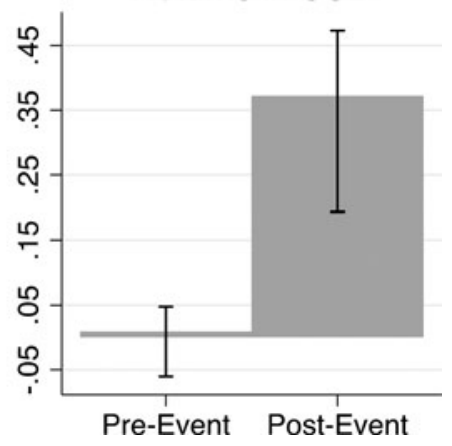

Figure 1. Average volatility ratios.

\section{Empirical results}

Before we discuss our main results, we provide evidence to justify our proposed identification strategy. Figure 1 shows the mean pre- and post-event volatility ratios. To compute these averages, we consider all the events listed in Table 1, regardless of their type. ${ }^{18}$ The error bars indicate 95 percent confidence intervals, calculated using the empirical distribution of the test statistics obtained following the iterative procedure described above.

Figure 1 indicates that post-event volatility ratios exceeded pre-event volatility ratios, on average. More importantly, it shows how asset prices responded to the political events. Volatility did not change in the two days before these events became publicly known. In contrast, relative to the previous day, volatility increased in the trading day immediately following these events' public disclosure. Therefore, the evidence suggests that these events took investors by surprise.

We now proceed to examine the effect of the different types of events on financial volatility (hypothesis $H_{A}$ ). Table 2 shows the average values of the pre- and post-event volatility ratios across different political events. The $t$-statistics, reported in parentheses, are calculated as described above, and setting $V R_{0}=0$. Right below these figures, we present the bootstrap p-values for $\operatorname{Pr}\left(t_{c}^{\eta}>t_{c}^{\kappa}\right)$ and $\operatorname{Pr}\left(t_{c}^{\eta}>t_{c}^{\tau}\right)$ obtained from the empirical distribution of $t_{c}^{\eta}$ developed using the iterative process described above.

Consider first all the events included in this study, regardless of their type. Based on the results presented in Table 2, we can reject both null hypotheses $H_{0}$, and $H_{0}^{\prime}$. Instead, as its first column indicates, our findings are consistent with $H_{A}$. Irrespective of how market returns are measured, none of the pre-event volatility ratios has a positive value; whereas every post-event volatility ratio is positive. As such, we can conclude that asset prices responded to this set of events.

In the case of nominal returns depicted in Figure 1, the average post-event volatility ratio across all political events is $0.213\left(t_{c}^{\tau}=4.239\right.$, p-value $\left.=0.000\right)$. In contrast, the average pre-event volatility ratio across all political events when returns are measured in nominal terms is 0.002 $\left(t_{c}^{\kappa}=0.093\right.$, p-value $\left.=0.397\right)$. The positivity of $\overline{V R^{\tau}}$ combined with $\overline{V R^{\kappa}} \leq 0$, means that volatility increases in the first-trading day when the Argentine stock market can respond to the news of these events, compared to its chronological neighbor, the trading day before the events become publicly known. The effect of these political shocks on financial volatility is not only statistically, but also substantially significant. The average post-event volatility ratio of 0.213 for nominal returns implies a 24 percent post-event volatility increase.

An examination of how the different types of policy-shifting events affect asset prices reveals that we can reject the null hypotheses $H_{0}$, and $H_{0}^{\prime}$, for some, but not all, of these events. In accordance with $H_{A}$, volatility increases in the days immediately following changes in the country's

${ }^{18} \overline{V R^{\kappa}}=\frac{1}{n} \sum_{i=1}^{n} V R_{v=i}^{\kappa}, \quad \overline{V R^{\tau}}=\frac{1}{n} \sum_{i=1}^{n} V R_{v=i}^{\tau}$, and $n=106$. 
Table 2. Effect of political shocks on financial volatility

\begin{tabular}{|c|c|c|c|c|c|c|c|c|}
\hline & All events & $\begin{array}{l}\text { Change in } \\
\text { economic } \\
\text { stewardship }\end{array}$ & $\begin{array}{l}\text { Change in } \\
\text { econ. } \\
\text { Steward } \\
\text { (same } \\
\text { gov.) }\end{array}$ & $\begin{array}{c}\text { Change in } \\
\text { administration }\end{array}$ & $\begin{array}{c}\text { Irregular } \\
\text { change in } \\
\text { administration }\end{array}$ & $\begin{array}{l}\text { Planned } \\
\text { succession }\end{array}$ & $\begin{array}{l}\text { National } \\
\text { election }\end{array}$ & $\begin{array}{c}\text { Terrorist } \\
\text { act }\end{array}$ \\
\hline \multicolumn{9}{|l|}{ Panel A: Nominal returns } \\
\hline \multirow[t]{2}{*}{ Pre-event volatility } & $\begin{array}{c}0.002 \\
(0.093)\end{array}$ & $\begin{array}{l}0.015 \\
(0.399)\end{array}$ & $\begin{array}{c}0.033 \\
(0.681)\end{array}$ & $\begin{array}{l}-0.086 \\
(-2.698)\end{array}$ & $\begin{array}{l}-0.075 \\
(-1.432)\end{array}$ & $\begin{array}{l}-0.094 \\
(-2.272)\end{array}$ & $\begin{array}{c}0.056 \\
(0.740)\end{array}$ & $\begin{array}{l}-0.046 \\
(-1.897)\end{array}$ \\
\hline & 0.415 & 0.299 & 0.199 & 0.931 & 0.757 & 0.871 & 0.174 & 0.889 \\
\hline \multirow[t]{3}{*}{ Post-event volatility } & 0.213 & 0.267 & 0.276 & 0.261 & 0.540 & 0.052 & 0.342 & -0.043 \\
\hline & (4.239) & (3.730) & (3.304) & $(2.235)$ & $(2.367)$ & $(0.684)$ & $(2.426)$ & $(-1.765)$ \\
\hline & $0.000^{\star \star \star}$ & $0.000^{\star \star \star}$ & $0.000^{\star \star \star}$ & $0.001^{\star \star \star}$ & $0.001^{\star \star \star}$ & 0.188 & $0.000^{\star \star \star}$ & 0.876 \\
\hline \multicolumn{9}{|c|}{ Panel B: Inflation adjusted returns } \\
\hline \multirow[t]{2}{*}{ Pre-event volatility } & $\begin{array}{l}-0.005 \\
(-0.564)\end{array}$ & $\begin{array}{l}-0.008 \\
(-0.824)\end{array}$ & $\begin{array}{l}-0.006 \\
(-0.553)\end{array}$ & $\begin{array}{l}-0.031 \\
(-3.192)\end{array}$ & $\begin{array}{l}-0.020 \\
(-1.062)\end{array}$ & $\begin{array}{l}-0.039 \\
(-4.087)\end{array}$ & $\begin{array}{c}0.032 \\
(1.087)\end{array}$ & $\begin{array}{l}-0.025 \\
(-3.696)\end{array}$ \\
\hline & 0.161 & 0.661 & 0.583 & 0.901 & 0.597 & 0.899 & $0.055^{\star}$ & 0.938 \\
\hline \multirow[t]{2}{*}{ Post-event volatility } & $\begin{array}{c}0.132 \\
(3.794)\end{array}$ & $\begin{array}{c}0.138 \\
(2.881)\end{array}$ & $\begin{array}{c}0.152 \\
(2.576)\end{array}$ & $\begin{array}{c}0.120 \\
(1.888)\end{array}$ & $\begin{array}{c}0.304 \\
(2.411)\end{array}$ & $\begin{array}{c}-0.018 \\
(-1.366)\end{array}$ & $\begin{array}{l}0.195 \\
(1965)\end{array}$ & $\begin{array}{c}0.053 \\
(1.076)\end{array}$ \\
\hline & $0.000^{\star \star \star}$ & $0.000^{\star \star \star}$ & $0.000^{\star * \star}$ & $0.000^{\star \star \star}$ & $0.000^{\star \star \star}$ & 0.670 & $0.000^{\star \star \star}$ & $0.062^{*}$ \\
\hline \multicolumn{9}{|c|}{ Panel C: Real returns in US dollars } \\
\hline \multirow[t]{2}{*}{ Pre-event volatility } & $\begin{array}{c}0.009 \\
(0.283)\end{array}$ & $\begin{array}{c}0.040 \\
(0.860)\end{array}$ & $\begin{array}{c}0.060 \\
(1.039)\end{array}$ & $\begin{array}{l}-0.071 \\
(-1.381)\end{array}$ & $\begin{array}{l}-0.106 \\
(-1.703)\end{array}$ & $\begin{array}{l}-0.044 \\
(-0.568)\end{array}$ & $\begin{array}{c}0.021 \\
(0.266)\end{array}$ & $\begin{array}{l}-0.038 \\
(-1.022)\end{array}$ \\
\hline & 0.318 & 0.137 & $0.096^{*}$ & 0.805 & 0.792 & 0.603 & 0.326 & 0.739 \\
\hline Pre-event volatility & $\begin{array}{l}0.372 \\
(4.719) \\
0.000^{\star \star \star}\end{array}$ & $\begin{array}{l}0.484 \\
(3.914) \\
0.000^{\star \star \star}\end{array}$ & $\begin{array}{l}0.446 \\
(3.372) \\
0.000^{\star \star \star}\end{array}$ & $\begin{array}{l}0.523 \\
(2.310) \\
0.001^{\star \star \star}\end{array}$ & $\begin{array}{l}0.737 \\
(2.130) \\
0.003^{\star \star \star}\end{array}$ & $\begin{array}{c}0.362 \\
(1.193) \\
0.057^{\star \star}\end{array}$ & $\begin{array}{l}0.420 \\
(2.495) \\
0.000^{\star \star \star}\end{array}$ & $\begin{array}{c}0.117 \\
(0.887) \\
0.125\end{array}$ \\
\hline Obs. & 125 & 62 & 47 & 21 & 9 & 12 & 28 & 27 \\
\hline
\end{tabular}

economic stewardship, irregular government turnovers, and national elections. We cannot reject the null hypothesis $H_{0}$ of no changes in stock-market volatility, however, in the case of terrorist attacks, or when a new administration is inaugurated. As with all events, these results hold if market returns are measured in nominal terms, in local consumption units, or in US consumption units.

With respect to the size of these effects, the most significant increase in post-event volatility is associated with irregular government turnovers (coup d'états, presidential death, and resignations). The average post-event volatility ratio of 0.737 for real returns expressed in US dollars implies a post-event volatility increase of roughly 100 percent. National elections are also a source of considerable financial volatility. In the case of nominal returns, the arrival of post-electoral news is associated with a 40 percent increase in volatility. The effect of electoral outcomes on asset prices is comparable to how the market reacts to changes in the country's economic stewardship. Whenever the person in charge of the economy changes, regardless of whether the country's administration changes or not, the post-event volatility ratios are also positive and statistically significant. In the case of inflation adjusted returns, this type of event spurs increases in financial volatility that range from a minimum of 15 percent to a maximum of 62 percent.

Our findings also indicate that trading days immediately following the inauguration of a new administration do not exhibit any increases in volatility. In contrast to irregular government turnovers, the exact timing of a planned succession is public information, and determined sufficiently far in advance. Moreover, the identity of most high-ranking officials is usually revealed a few days in advance of the inauguration. As such, the results presented in Table 2 reflect that by the time a new administration was sworn in, investors had already priced in to the market the policy changes associated with the government change.

In the case of terrorist attacks, the apparent lack of market reaction to this type of events may be masking important differences between economic activities. As Berrebi and Klor (2008) note, terror acts are usually a source of idiosyncratic rather than systematic risk. Their analysis of Israeli 
companies reveals that terrorism has a negative impact on non-defense-related companies, but a positive one on defense-related companies. Chesney et al. (2011) reach a similar conclusion. Using data from different Financial Times Stock Exchange (FTSE) indices, they show that prices react negatively to terrorism in the insurance, travel, airline, oil and gas, and financial and banking sectors. Terrorist attacks, however, have a positive impact on the defense and pharmaceutical/ biotechnology industries. Therefore, as reflected on the results reported in Table 2, the net effect of terrorist attacks on an aggregate market index can be indeterminate.

Overall, our results indicate that, relative to the previous trading day, average volatility increases in the trading day immediately volatility increases in the trading day immediately following the public disclosure of changes in the country's economic stewardship, irregular government turnovers, and national elections. Foreseeable events, and shocks that have a heterogeneous impact across the economy, are not a significant source of variance risk. As such, we interpret these findings as evidence in support of the view that market valuations respond to the policy uncertainty associated with unexpected and consequential political shocks.

\subsection{Robustness tests}

We generated the results presented in Table 2 using our three-day estimation period as delineated above. Note that we identified day zero as the trading day immediately before an event became publicly known, and day one as the first trading day when the stock market could respond to the news of the event. Pairs of consecutive trading days, however, do not always correspond to two consecutive calendar dates due to weekends and holiday closures. For example, if the announcement of the economic minister's resignation is made public on a Friday after the close of trading, then the first-trading day when the stock market can respond to the news would be Monday, rather than Saturday. Similarly, when news of an event is released right before a holiday closing, the next trading day (i.e., post-holiday) takes place in a non-consecutive calendar date.

Although some market closings are preannounced and coincide with general holidays (such as Christmas, New Year, and other national celebrations), some other ones pertain exclusively to financial institutions. These so-called bank holidays are usually emergency shutdowns declared by the authorities to prevent financial disasters. These closures can be, thus, driven by the same factors that trigger some of the events in our sample. For instance, the Buenos Aires exchange remained closed for a period of 12 days following the 1976 coup (from Wednesday 24th March to Monday 5th April). In addition, it is not uncommon to publicize major policyshifting events around weekend and holiday closings. The announcement of a change in the country's economic stewardship is a case in point. Of the 47 cases in our sample where such a change occurred within an existing administration, 22 took place after the close of trading on the eve of a weekend/holiday, or during the weekend/holiday day(s).

Considering all the events in our sample, 14 of them took place during a three-day window with non-consecutive calendar days due to holiday closings. In the case of weekends, five government inaugurations, and all the elections in our sample were held on Sundays. Therefore, despite having a three-day window involving non-consecutive days, these events took place immediately before the first calendar day when the stock market could respond to the news of the event. If we exclude these cases, a total of 45 events in our sample took place during a three-day window with non-consecutive calendar days due to weekends. One could still argue that any three-day window that straddles a weekend should be counted as one involving non-consecutive calendar days (i.e., only events that take place on a Tuesday, Wednesday, or Thursday conform to a three-day window with consecutive calendar days). Under this definition, a total of 77 events in our sample possess a three-day window involving non-consecutive days. If we also account for holiday closings, then as many as 91 of the events in our sample took place during three-day windows involving non-consecutive calendar days. 
As mentioned above, we reviewed every story that received front-page coverage by the newspaper Clarin in each of our three-day event windows to make sure that our estimates are free of contamination from other shocks. Nonetheless, the existence of non-consecutive calendar days within each window raises another possible identification threat. As French and Roll (1986) note, asset returns can display a difference in volatility between trading and non-trading periods due to dissimilarities in the flow of information. In addition to this closed-market effect, the abnormality of post-weekend price returns is also a well-documented fact in the financial literature (Thaler, 1987). It is, thus, possible that our results may be susceptible to these holiday and weekend effects.

To address these issues, we replicate the analysis presented in Table 2 excluding events that took place during a three-day window with non-consecutive calendar days. We present our findings in Table 3, panels A through C. To avoid clutter, only the results for returns expressed in US consumption units are shown. We obtain very similar findings when returns are measured in local consumption units both in nominal as well as in real terms. As mentioned above, some of the political events listed in Table 1 took place mostly around weekends/holidays. To account for this fact, we only report the average pre- and post-event volatility ratios for categories of events with five observations or more.

An examination of the results in Table 3 indicates that irrespective of these alternative specifications of our three-day window and sample sizes, the effect of political shocks on financial volatility remains robust and statistically significant. Therefore, we are confident that our findings are not driven by weekend/holiday effects.

As a final robustness check on our results, we examine the effect of political shocks on financial volatility using intraday price movements. As Andersen and Bollerslev (1998) note, a test for volatility responses to specific events should account for both the inter-daily volatility process as well as the intraday pattern. The $\operatorname{GARCH}(1,1)$ specification that we use treats volatility as being constant over the trading day. As such, our estimates may constitute a noisy measure of the underlying latent volatility. For example, suppose that asset prices fluctuate wildly after an unexpected policy-shifting event becomes publicly known; but nonetheless, end up close to the previous day's closing price by the end of the trading day. If this were the case, then our inter-day estimate would falsely signal a low volatility state.

The intraday data only cover the period between 14th March 1994 and 30th March 2020. In addition, high-frequency returns, covering a short time span (such as five-minute intervals) are not available. Instead, we only have information on daily opening, closing, high, and low prices. Nevertheless, we can use these intraday price movements to evaluate the robustness of our previous findings. To measure volatility, we use the true range (TR), a well-known technical analysis indicator. ${ }^{19}$ Following Forman (2006), we normalize the TR to make meaningful comparisons over time. The normalized TR (NTR) at time $t$ is calculated as follows:

$$
N T R_{t}=\left[\max \left(\text { high }_{t}, \text { close }_{t-1}\right)-\min \left(\text { low }_{t}-\text { close }_{t-1}\right)\right] / \text { close }_{t-1} \text {. }
$$

A low NTR value indicates a period with small ranges (quiet days). In contrast, a large NTR value indicates increased volatility in the market. Using these NTR values, we calculate the pre- and post-volatility ratios following the procedures laid out in Section 3.2. We also follow the same steps delineated in Section 3.3, restricting our attention to observations corresponding to days in which the events listed in Table 1 did not take place, and setting $V R_{0}=0$ to calculate our $t$-statistics.

\footnotetext{
${ }^{19}$ The range of a day's trading is simply the difference between its high and low prices. Sometimes markets open much higher or much lower than their previous close. To account for this gap, the TR also accounts for situations when the previous day's closing price is outside the current day's trading range.
} 
Table 3. Robustness tests

\begin{tabular}{|c|c|c|c|c|c|c|c|c|}
\hline & All events & $\begin{array}{l}\text { Change in } \\
\text { economic } \\
\text { stewardship }\end{array}$ & $\begin{array}{l}\text { Change in } \\
\text { econ. } \\
\text { steward } \\
\text { (same } \\
\text { gov.) }\end{array}$ & $\begin{array}{c}\text { Change in } \\
\text { administration }\end{array}$ & $\begin{array}{c}\text { Irregular } \\
\text { change in } \\
\text { administration }\end{array}$ & $\begin{array}{l}\text { Planned } \\
\text { succession }\end{array}$ & $\begin{array}{l}\text { National } \\
\text { election }\end{array}$ & $\begin{array}{c}\text { Terrorist } \\
\text { act }\end{array}$ \\
\hline \multicolumn{9}{|c|}{ Panel A: Excluding holiday closures } \\
\hline \multirow[t]{2}{*}{ Pre-event volatility } & $\begin{array}{c}0.014 \\
(0.424)\end{array}$ & $\begin{array}{c}0.052 \\
(1.005)\end{array}$ & $\begin{array}{c}0.093 \\
(1.437)\end{array}$ & $\begin{array}{l}-0.133 \\
(-3.754)\end{array}$ & $\begin{array}{l}-0.087 \\
(-1.298)\end{array}$ & $\begin{array}{c}-0.179 \\
(-10.863)\end{array}$ & $\begin{array}{c}0.021 \\
(0.266)\end{array}$ & $\begin{array}{c}-0.036 \\
(0.881)\end{array}$ \\
\hline & 0.267 & 0.101 & $0.033^{\star \star}$ & 0.961 & 0.724 & 0.995 & 0.335 & 0.707 \\
\hline \multirow[t]{3}{*}{ Post-event Volatility } & 0.388 & 0.494 & 0.419 & 0.706 & 0.808 & 0.604 & 0.420 & 0.136 \\
\hline & $(4.606)$ & $(3.689)$ & (3.087) & $(2.502)$ & $(2.106)$ & $(1.382)$ & (2.495) & $(0.916)$ \\
\hline & $0.000^{\star * \star}$ & $0.000^{\star \star \star}$ & $0.000^{\star \star \star}$ & $0.000^{\star * \star}$ & $0.003^{\star \star \star}$ & $0.032^{\star \star}$ & $0.000^{\star \star \star}$ & 0.118 \\
\hline Obs. & 111 & 53 & 41 & 16 & 8 & 8 & 28 & 24 \\
\hline \multicolumn{9}{|c|}{ Panel B: Excluding holiday and weekend closures (except for elections and planned successions) } \\
\hline \multirow[t]{2}{*}{ Pre-EVENT } & $\begin{array}{c}0.009 \\
(0.179)\end{array}$ & $\begin{array}{c}0.070 \\
(0.763)\end{array}$ & $\begin{array}{c}0.165 \\
(1.150)\end{array}$ & $\begin{array}{l}-0.126 \\
(-2.679)\end{array}$ & $\begin{array}{c}-0.062 \\
(0.560)\end{array}$ & $\begin{array}{c}-0.171 \\
(-10.396)\end{array}$ & $\begin{array}{c}0.021 \\
(0.266)\end{array}$ & $\begin{array}{l}-0.120 \\
(-3.115)\end{array}$ \\
\hline & 0.354 & 0.158 & $0.067^{\star}$ & 0.903 & 0.564 & 0.993 & 0.335 & 0.909 \\
\hline \multirow[t]{3}{*}{ Post-event Volatility } & 0.392 & 0.498 & 0.250 & 0.859 & 1.190 & 0.623 & 0.420 & 0.026 \\
\hline & (3.495) & $(2.260)$ & $(1.167)$ & $(2.344)$ & $(2.154)$ & $(1.234)$ & (2.495) & $(0.385)$ \\
\hline & $0.000^{\star \star \star}$ & $0.001^{\star \star \star}$ & $0.063^{\star}$ & $0.000^{\star \star \star}$ & $0.005^{\star \star \star}$ & $0.048^{\star \star}$ & $0.000^{\star \star \star}$ & 0.275 \\
\hline Obs. & 66 & 25 & 15 & 12 & 5 & 7 & 28 & 10 \\
\hline \multicolumn{9}{|c|}{ Panel C: Excluding holidays and all weekend closures } \\
\hline \multirow[t]{3}{*}{ Pre-event volatility } & 0.019 & 0.104 & 0.165 & -0.104 & -0.062 & N/A & $\mathrm{N} / \mathrm{A}$ & -0.120 \\
\hline & $(0.281)$ & $(1.018)$ & $(1.150)$ & $(-1.486)$ & $(0.560)$ & N/A & $\mathrm{N} / \mathrm{A}$ & $(-3.115)$ \\
\hline & 0.326 & $0.093^{*}$ & $0.068^{*}$ & 0.751 & 0.547 & N/A & $\mathrm{N} / \mathrm{A}$ & 0.918 \\
\hline \multirow[t]{3}{*}{ Post-event Volatility } & 0.288 & 0.362 & 0.250 & 0.751 & 1.190 & N/A & $\mathrm{N} / \mathrm{A}$ & 0.026 \\
\hline & $(2.084)$ & $(1.784)$ & $(1.167)$ & $(1.907)$ & $(2.154)$ & $\mathrm{N} / \mathrm{A}$ & $\mathrm{N} / \mathrm{A}$ & $(0.385)$ \\
\hline & $0.002^{\star * \star}$ & $0.009^{\star \star \star}$ & $0.064^{\star}$ & $0.007^{\star \star \star}$ & $0.005^{\star \star \star}$ & $\mathrm{N} / \mathrm{A}$ & $\mathrm{N} / \mathrm{A}$ & 0.283 \\
\hline Obs. & 34 & 22 & 15 & 8 & 5 & 3 & 0 & 10 \\
\hline \multicolumn{9}{|c|}{ Panel D: Intraday asset prices } \\
\hline \multirow[t]{3}{*}{ Pre-event volatility } & 0.003 & 0.074 & -0.056 & 0.359 & $\mathrm{~N} / \mathrm{A}$ & 0.250 & -0.104 & $\mathrm{~N} / \mathrm{A}$ \\
\hline & $(0.030)$ & $(0.499)$ & $(-0.316)$ & $(1.751)$ & N/A & $(1.364)$ & $(0.577)$ & N/A \\
\hline & 0.484 & 0.317 & 0.618 & $0.051^{*}$ & $\mathrm{~N} / \mathrm{A}$ & 0.107 & 0.706 & $\mathrm{~N} / \mathrm{A}$ \\
\hline \multirow[t]{3}{*}{ Post-event Volatility } & 0.428 & 0.514 & 0.625 & 0.025 & $\mathrm{~N} / \mathrm{A}$ & -0.061 & 0.477 & $\mathrm{~N} / \mathrm{A}$ \\
\hline & (3.090) & (2.481) & $(2.303)$ & $(0.140)$ & N/A & $(0.305)$ & (2.616) & N/A \\
\hline & $0.001^{\star \star \star}$ & $0.009^{\star \star \star}$ & $0.014^{\star \star}$ & 0.487 & $\mathrm{~N} / \mathrm{A}$ & 0.610 & $0.007^{\star \star \star}$ & $\mathrm{N} / \mathrm{A}$ \\
\hline Obs. & 50 & 27 & 20 & 9 & 2 & 7 & 20 & 1 \\
\hline
\end{tabular}

Panel D of Table 3 shows the average values of the pre- and post-event volatility ratios across different political events calculated using intraday price movements. For comparability, only the results for returns expressed in US consumption units are shown. Measuring returns in local consumption units in either nominal or real terms yields very similar results. Because the intraday data do not cover the period between 2nd January 1967 and 13th March 1994, some of the political events listed in Table 1 cannot be examined (e.g., only two irregular government changes, and a single terrorist act occurred during this time frame). Therefore, we only report the average pre- and post-event volatility ratios for categories of events with five observations or more.

The results are analogous to those reported in Table 2. The only difference is that trading days immediately following a change in government do not exhibit any increases in volatility. Note that only two irregular government changes took place during the period 1994 and 2020; therefore, most of the observations in this category of events correspond to planned successions (seven out of nine). As discussed above, investors typically priced in to the market the policy changes associated with this type of government change. Therefore, if anything, the analysis based on the intraday price movements reinforces our main findings regarding the effects political shocks on financial volatility. ${ }^{20}$

\footnotetext{
${ }^{20}$ For additional robustness tests, see online Appendix B, where we compare the variance risk of event and non-event days; and online Appendix C, where we examine if market actors' expectations during the period under study were state dependent.
} 


\section{Conclusions}

In this paper, we examine how political uncertainty affects financial volatility using daily stockmarket prices from Argentina between 1967 and 2020. We consider a wide range of political shocks, including changes in a country's economic stewardship, national elections, coup d'états, wars, and terrorist attacks. We exploit the precise timing of these events, and adopt a very narrow event window to minimize the presence of contaminating information. By focusing on how returns respond to these events, while holding constant other confounders that the typical cross-country design cannot, we advance our understanding of the role of political risk in the pricing of financial assets.

Our results indicate that volatility increases in the first-trading day when the stock market can respond to the news of a major policy-shifting event, compared to its chronological neighbor, the trading day before the event is publicly known. The extent to which returns are affected by these political shocks, however, varies by their predictability as well as by the danger that they pose to the entire market. Foreseeable events, and shocks that have idiosyncratic effects, are not a significant source of systemic risk.

Although we highlight the link between politics and broad market risk, further examination could explore idiosyncratic political risk, by looking at how different types of policy-shifting events affect an individual asset (a specific company's stock), a group of assets (a distinct sector's stocks), or a specific asset class (such as bonds or options). Our inquiry could also be extended to other countries displaying significant instances of political unrest. In addition, subject to data availability, one could refine the analysis using higher frequency returns (i.e., five-minutes), as well as other volatility indicators, such as the CBOE volatility index (VIX). In all these cases, the approach introduced in this paper can be fruitfully used to gauge how capital markets respond to the policy uncertainty associated with unexpected political risks.

Finally, although we place our focus on financial volatility, the results in this paper also have implications for the analysis of market returns and risk pricing. When asset prices fall, investors often liquidate their current positions until the expected return rises to compensate for the risk. Volatility increases, in turn, require even lower prices to compensate investors for holding volatile assets. Because the type of events studied in this paper trigger volatility bouts, we should also consider their second-order effects on the public's material well-being. Therefore, one of the lessons that can be learned from this study is that, by depressing investment and real activity, policy uncertainty can pose a significant challenge to economic growth.

Supplementary material. The supplementary material for this article can be found at https://doi.org/10.1017/psrm.2021.58

\section{References}

Aizenman J and Marion N (1993) Policy uncertainty, persistence and growth. Review of International Economics 1, 145-163. Aktas N, de Bodt E and Cousin J-G (2007) Event studies with a contaminated estimation period. Journal of Corporate Finance 13, 129-145.

Amihud Y and Wohl A (2004) Political news and stock prices: the case of Saddam Hussein contracts. Journal of Banking \& Finance 28, 1185-1200.

Andersen TG and Bollerslev T (1998) Deutsche mark - dollar volatility: intraday activity patterns, macroeconomic announcements, and longer run dependencies. Journal of Finance 53, 219-265.

Arin KP, Ciferri D and Spagnolo N (2008) The price of terror: the effects of terrorism on stock market returns and volatility. Economics Letters 101, 164-167.

Baker SR, Bloom N and Davis SJ (2016) Measuring economic policy uncertainty. Quarterly Journal of Economics 131, 15931636.

Baker SR, Bloom N and Terry SJ (2020) Does Uncertainty Reduce Growth? Unpublished manuscript, Department of Economics, Stanford University.

Berkman H, Jacobsen B and Lee JB (2011) Time-varying rare disaster risk and stock returns. Journal of Financial Economics 101, 313-332.

Bernanke BS (1983) Irreversibility, uncertainty, and cyclical investment. Quarterly Journal of Economics 98, 85-106. 
Bernhard W and Leblang D (2006) Democratic Processes and Financial Markets: Pricing Politics. New York: Cambridge University Press.

Berrebi C and Klor E (2008) The impact of terrorism on the defence industry. Economica 77, 518-543.

Bialkowski J, Gottschalk K and Wisniewski TP (2008) Stock market volatility around national elections. Journal of Banking \& Finance 32, 1941-1953.

Bittlingmayer G (1998) Output, stock volatility, and political uncertainty in a natural experiment: Germany, 1880-1940. Journal of Finance 53, 2243-2257.

Boutchkova M, Doshi H, Durnev A and Molchanov A (2012) Precarious politics and return volatility. Review of Financial Studies 25, 1111-1154.

Brogaard J and Detzel A (2015) The asset-pricing implications of government economic policy uncertainty. Management Science 61, 1-247.

Brounrn D and Derwall J (2010) The impact of terrorist attacks on international stock markets. European Financial Management 16, 585-598.

Carnahan D and Saiegh S (2020) Electoral Uncertainty and Financial Volatility: Evidence from Two-Round Presidential Races in Emerging Markets, unpublished manuscript, Department of Political Science, University of California San Diego.

Chesney M, Reshetar G and Karaman M (2011) The impact of terrorism on financial markets: an empirical study. Journal of Banking \& Finance 35, 253-267.

Clayton MC, Hartzell JC and Rosenberg J (2005) The impact of CEO turnover on equity volatility. Journal of Business 78, 1779-1808.

Cruces JJ and Garcia-Cicco J (2012) Grading Latin American presidents: a view from the stock markets, Working paper No. 37, Escuela de Economía Francisco Valsecchi, Universidad Católica Argentina.

Dai L and Zhang B (2019) Political uncertainty and finance: a survey. Asia-Pacific Journal of Financial Studies 48, 307-333.

Dasgupta A and Ziblatt D (2015) How did Britain democratize? Views from the sovereign bond market. Journal of Economic History 75, 1-29.

Dixit AK and Pindyck RS (1994) Investment under Uncertainty. Princeton: Princeton University Press.

Dube A, Kaplan E and Naidu S (2011) Coups, corporations, and classified information. Quarterly Journal of Economics 126, 1375-1409.

Dubofsky DA (1991) Volatility increases subsequent to NYSE and AMEX stock splits. Journal of Finance 46, 421-431.

Dyckman T, Philbrick D and Stephan J (1984) A comparison of event study methodologies using daily stock returns: a simulation approach. Journal of Accounting Research 22, 1-30.

Fama EF (1970) Efficient capital markets: a review of theory and empirical work. Journal of Finance 25, 383-417.

Fisman R (2001) Estimating the value of political connections. American Economic Review 91, 1095-1102.

Forman J (2006) Cross-market evaluations with normalized average true range. Technical Analysis of Stocks \& Commodities 24, 60-63.

French K and Roll R (1986) Stock return variances: the arrival of information and the reaction of traders. Journal of Financial Economics 17, 5-26.

Girardi D and Bowles S (2018) Institution shocks and economic outcomes: Allende's election, Pinochet's coup and the Santiago stock market. Journal of Development Economics 134, 16-27.

Harrington SE and Shrider DG (2007) All events induce variance: analyzing abnormal returns when effects vary across firms. Journal of Financial and Quantitative Analysis 42, 229-256.

Incerti D and Incerti T (2019) Are regime changes always bad economics? Evidence from daily financial data, unpublished manuscript. Department of Political Science, Yale University.

Jones BF and Olken BA (2005) Do leaders matter? National leadership and growth since world War II. Quarterly Journal of Economics 120, 835-864.

Kelly B, Pastor L and Veronesi P (2016) The price of political uncertainty: theory and evidence from the option market. Journal of Finance 71, 2417-2480.

Leblang D and Mukherjee B (2004) Presidential elections and the stock market: comparing Markov-switching and fractionally integrated GARCH models of volatility. Political Analysis 12, 296-322.

Leblang D and Satyanath S (2008) Politically generated uncertainty and currency crises: theory, tests, and forecasts. Journal of International Money and Finance 27, 480-497.

Liu LX, Shu H and John Wei KC (2017) The impacts of political uncertainty on asset prices: evidence from the Bo scandal in China. Journal of Financial Economics 125, 286-310.

Pantzalis C, Stangeland DA and Turtle H (2000) Political elections and the resolution of uncertainty: the international evidence. Journal of Banking \& Finance 24, 1575-1604.

Park NK (2004) A guide to using event study methods in multi-country settings. Strategic Management Journal 25, 655-668.

Pastor L and Veronesi P (2013) Political uncertainty and risk premia. Journal of Financial Economics 110, 520-545.

Przeworski A (2005) Democracy as an equilibrium. Public Choice 123, 253-273.

Ramey G and Ramey VA (1995) Cross-country evidence on the link between volatility and growth. American Economic Review 85, 1138-1151. 
Rigobon R and Sack B (2005) The effects of war risk on US financial markets. Journal of Banking \& Finance 29, 1769-1789. Sattler T (2013) Do markets punish left governments? Journal of Politics 75, 343-356.

Savickas R (2003) Event-induced volatility and tests for abnormal performance. Journal of Financial Research 26, 165-178.

Thaler R (1987) Seasonal movements in security prices II: weekend, holiday, turn of the month, and intraday effects. Journal of Economic Perspectives 1, 169-177.

Wisniewski TP (2016) Is there a link between politics and stock returns? A literature survey. International Review of Financial Analysis 47, 15-23.

Zussman A and Zussman N (2006) Assassinations: evaluating the effectiveness of an Israeli counterterrorism policy using stock market data. Journal of Economic Perspectives 20, 193-206.

Zussman A, Zussman N and Nielsen M (2008) Asset market perspectives on the Israeli-Palestinian conflict. Economica 75, $84-115$.

Cite this article: Carnahan D, Saiegh S (2021). Political shocks and asset prices. Political Science Research and Methods 1-18. https://doi.org/10.1017/psrm.2021.58 